\title{
CO-CREATION OF SERVICE BRAND MEANING: INITIAL FINDINGS FROM AN EXPLORATION OF BANK BRANDING IN THE VIETNAMESE RETAIL BANKING SECTOR
}

\section{Kieran Tierney, RMIT University, Vietnam}

Kate Westberg, RMIT University, Melbourne

Ingo O. Karpen, RMIT University, Melbourne

\begin{abstract}
Much of the extant literature on brand meaning co-creation suggests the importance of managing the knowledge of various actors and brand constituting factors that influence the co-creation of brand meaning. However, there is no apparent discussion on how to manage the identification of brand constituting factors and knowledge exchange between various actors. The purpose of this research is to explore the co-creation process and propose a conceptual framework for brand meaning co-creation with multiple actors. Preliminary analysis of banking customer interviews reveals a range of factors relevant to brand meaning co-creation. Additionally, there is an emerging picture from the data of variant brand narratives developing between the customers, front-line staff and brand managers involved in this ongoing pilot study and other actors such as peers and family.
\end{abstract}

References Available Upon Request. 